\title{
Are resort operators in the ecotourism area demanding an environmental protection culture? The case of Lake Kenyir, Malaysia
}

\author{
N. Yusof, I. Said, Z. Osman \& M. F. Che Daud \\ School of Housing, Building and Planning, \\ University Sains Malaysia, Malaysia
}

\begin{abstract}
The negative impact of tourism development to the environment has received considerable debate in the past. Many have agreed that the success of a tourism industry is dependent upon wise usage and management of the natural environment. There is a need to examine whether the value and practices of the main players, especially the resort operators, are not destructive to the environment. However, limited attention has been given to the 'environmental sensitive cultures' of the service provider. The present study tries to fill in the gap by providing an empirical support to investigate whether resort operators in an ecotourism area adopt a certain organisational culture that is harmonious to the environment. A questionnaire survey was administered to the six owners and fifty-one employees of all resort operators located at Lake Kenyir, Malaysia. The researchers theorized that organizational culture which leads to more environmental sensitive values and practices are more apparent amongst the resort organisations. This study found that most resort operators at Lake Kenyir implement an ecologically friendly approach in conducting business. Empirical findings indicate that the resort employees have environmentally sensitive values. The results gave rise to new policies to be introduced in an effort to enhance environmental protection. Magnitude limitations of this study prompt the possibility of conducting future researches to cover a broader spectrum, on a macro global scale.
\end{abstract}

Keywords: sustainable culture, environmental practices, resort operators, ecotourism. 


\section{Introduction}

The tourism industry was not regarded as an important economic activity in Malaysia up until the 1970s, but recently the tourism sector has ranked second in generating foreign exchange after the oil and gas industry (Kaur [1]). From January to September 2009, Malaysia recorded a total of 17,378,040 tourist arrivals (Malaysia Tourism Board [2]). This indicated an increase of $6.4 \%$ compared to $16,329,855$ for the same period in 2008. In September 2009 alone, tourist arrivals grew by $24.9 \%$ from 1,599,418 in September 2008 (ibid).

Recognizing the significance of the tourism industry, the government focused on promoting tourism where special promotions are undertaken to market niche tourism products such as eco-tourism (Department of Statistics [3]). Ecotourism stems from the words 'eco' and tourism, which can be inferred to as incorporating the aspects of ecology and tourism.

The wide range of natural assets in Malaysia, i.e. lakes, mangroves, limestone caves, mountains, waterfalls, islands, and wildlife makes ecotourism highly potential to be implemented in Malaysian tourism (Kaur [1]). There are at least five lake-based ecotourism destinations in Peninsular Malaysia, where two of them are natural lakes, while the remaining three are man-made lakes.

Despite the growing number of tourists visiting Malaysia, many of the ecotourism destinations are still struggling to attract visitors. This is an issue faced by resorts in one of the lake-based ecotourism destinations in Peninsular Malaysia. The lack of visiting tourist has caused a bad turnover which led to the resorts accruing huge annual losses and eventually forced the resorts to cease operations (Kedah Govt [4]). The lacks of tourists visiting the resorts are due to their dissatisfaction about the products and services offered in ecotourism destinations. There are many complaints on ecotourism resorts which neglect environmental factors. Resort operators are allegedly not adhering to environmental standards when it comes to products and services delivery (Bjork [5]). Environment qualities in most destinations are deteriorating because of improper waste disposal and the uncontrollable rate of ad hoc tourist development (Altinay and Hussain [6]). There are also problems of inadequate clean water supply and lack of support infrastructure (Harrison et al. [7]). It is not surprising those ecotourism destinations are only able to attract limited number of tourists.

The review of literature has found that the employment environmentally sensitive cultures when providing products and services have long been established. However, the condition is only on paper. Resort operators are accused as the main contributor for pollution in many tourism destinations (Hillary [8]). Statistics from United Kingdom's Environment Agency reveal that these small operators contribute about $60 \%$ of waste and $80 \%$ of pollution (Environment Agency [9]).

Many scholars have argued that most of the outlined policies are ineffective because they failed to understand and incorporate the nature and magnitude of businesses in ecotourism industry. Small business does not operate like large business. Small business operators are more likely to respond to niche market 
and often enough, the owner has a closer relationship to the business (Storey [10]). More attention should be given to understand how these businesses operate, before any tourism policy could be deployed to successfully address environmental problems (Thomas [11]).

The small firm size also indicated the increased likely hood to adapt to change (Storey [10]). It can be implied that small firms are replicating being elastic in nature. Therefore, environmental policies to safeguard the environment are able to be deployed by smaller companies and the effects from policy implementation will not be too significant to the company.

Despite the existence of literature which orientate on the need for the employment of environment sensitive culture, research which focus on the application of environmental sensitive cultures are very limited. Most research seems to revolve upon the development of sustainable tourism and tourists' environmental behaviour. Blangy and Wood [12] conducted a research which provided the guidelines for ecotourism.

This study attempts on investigating whether resort operators in an ecotourism area adopt certain organisational culture which is harmonious to the environment. The paper, first reviews the general definition of organisational culture. Second, discusses the environmental sensitive values and practices based on the limited studies in the context of housing industry, followed by a research methodology on a survey conducted on resort owners and employees. The result of the study is presented at the end of the paper.

\section{Organisational culture and environmentally sensitive culture}

Organizational culture has been defined in many ways by social science and management scholars, with a majority of the scholars adopting the definition by Hofstede [13] and Schein [14]. According to Hofstede [13], organisational culture consists of core values, norms, behaviours and artefacts shared by individuals in an organisation. Schein [15] views culture from an organisational learning perspective. The author defines culture as beliefs or assumption that have been invented and developed within the organisation. Subsequently, these cultures are taught to new members. Organizational cultures are two components that are interrelated; first, the shared values among organizational members and second, the expression of those values in terms of practices or behaviours in the way organizational members do their work (Kyriakidou and Gore [16]).

Values, on one hand, are invisible elements, i.e. the thought of organization members (Chatman and Jehn [17]). Practices on the other hand are observable, i.e. in terms of members' behaviour and speech (Ouchi [18]). According to Kilmann et al. [19], values are rarely put in black and white. Though not obvious, value provides meaning, direction and rules for organization behaviour (Gardner [20]; Sathe [21]). As such, organizational culture plays integration and coordination roles which holds organisation members together, aim at providing feeling of identity, ascertain acceptable norms and mutual understanding amongst members (Martin and Terblanche [22]). 
Global concern about environmental deterioration issues and the failure of macro level solutions to mitigate environmental problems have given rise to the need for all players to play their role in addressing these issues. In the context of ecotourism, the roles of resort operators are vital in tackling environmental issue at local level, in particular, the area where they operate. Dinan and Sargeant [23], claim that an effective approach to address environmental issue is that in any tourism activities, environment and the culture of local communities should be preserved, while at the same time fulfilling tourists' needs and maintaining the growth of the industry. Wahab and Pigram [24] warn that setting ecotourism as a development strategy to revive under developed areas, is in itself a potential threat to environment quality and would probably dwindle the area's natural resources.

Theoretically, the influx of tourist to a location would increase with the designation of the site as an ecotourism spot. As such, a proper management of influx tourist are required to minimise the adverse effects of tourism. Indeed as highlighted by Lynn and Brown [25], it has become evident that failure to properly manage the increasing numbers of tourists who visit protected areas has lead to a decline in biological diversity and exploitation of natural resources. In addressing these problems, three criteria must be put forward in any ecotourism development; (1) it should conserve the environment; (2) enhance the quality of life of the locals; and (3) avoid any forms of exploitation, Koens et al. [26].

Several researchers have emphasized the need for an environmental conscious culture in order to counter the adverse effects brought upon by ecotourism. Dunlap and Jones [27], define environmental culture as awareness about environmental problems and willingness to participate in activities which attempts to solve problems. The environmental sensitive cultures also suggests values and activities which relate to recycling, energy saving and environmentally friendly product or services (Bamberg [28]). In areas where there are influxes of tourists, waste processing facilities for garbage and sewage are seen as particularly important (Stern et al. [29]). This is as overdevelopment, overcrowding and solid waste production have been identified as the main factor which degrades the environment of a tourism destination (Alegre and Garau [30]).

Thomas [11], states that by recognizing the level of heterogeneity within tourism firms, it is possible to enhance policy measures employed. Rather than to look at all firms as being alike, the heterogeneity of small firms, i.e. market practices, planning approach, promotion, pricing and training have to be focussed in order to facilitate proper implementation.

A study in Sabah, Malaysia by Teh and Cabanban [31], regard biodiversity, water resources \& distribution and waste management are significant elements to influence tourist to revisit. In a more recent study, Blancas et al. [32] found that destinations which are highly sought after by tourists are those that implement waste and energy resource management. An earlier study by Lane [33], acknowledges that 'imported employees' is among the features of non environmental sensitivity. On the other hand, Jithendran and Baum [34] stress that employing local people is an evidence of awareness and sensitivity to socio- 
cultural and environmental aspects. This awareness will lead to increase conscientiousness on local tourism and give positive influence to its development. Revell et al. [35], analysed environmental practices of small and medium size businesses in the United Kingdom and concluded that businesses are actively engage in recycling, energy saving and other environmental protection activities. However little is known whether Malaysian resort operators are engaged in environmental sensitive values and practices. At this juncture, this study attempts to assess whether resort operators are engaged in environmental sensitive values and practices. The study conceptualises on environmental sensitive culture as values and practices that relate environment protection, energy saving, waste management or recycle and using of local product or employees.

\section{Methodology}

A standardised survey was conducted on employers and employees of all six Lake Kenyir resorts located in Peninsular Malaysia. The questionnaire consists of three sections. Section 1 consists of 7 questions on the general demographic profiles of the respondent. Section 2 has 14 items related to values and practices of resort operators when providing the service. This section was aimed at resort's employees. All items were adapted from previous studies. A four-point scale was used to measure the construct with the following levels: 1 - strongly disagree, 2 - disagree, 3 - agree and 4 - strongly agree. A four-point scale was used to avoid neutral answers available in a normal odd-point scale and to employ and element of force respondents to make decision on the questions asked (Garland [36]; Trochim [37]). Section 3 consists of 7 questions aimed at the resort's owner. This section utilises dichotomous scales (Yes and No) to seek clarification from the owner whether the resort practiced certain environmental sensitive practices.

The survey was conducted during the second week of August which is peak time for resorts in the area. Prior to the survey, the questionnaire was pilot-tested in June 2009 to ensure that the questions were not vague and well understood. Out of 70 employees and 6 owners identified in Lake Kenyir, the researchers successfully distributed the questionnaires to 51 employees and all owners. All questions were answered fully and thus were useable for analysis.

As a token of appreciation and to increase the response rate, each resort owner was given a memento and each respondent was given a ballpoint pen.

Descriptive analysis was used to analyses the data. The Statistical Package for Social Sciences (SPSS) software version 14.0 was utilised for analysis.

\section{Results and discussion}

\subsection{Respondent profile}

Out of 51 employees who responded, nearly 80 percent were between 20 and 35 years old, followed by 16 percent were between 36 and 55 years old. The 
remaining 4 percent was 19 and 18 years of age. Sixty-eight point six percent of the respondents were male. All were Malaysian and ninety-six percent were from Malay ethnic and the rest were Chinese and Indian. Fifty-two point nine percent were single, 41.2 while percent were married and the remaining were divorcee. Forty-five percent had attended secondary education, 21.6 percent and 19.6 percent received tertiary and primary education, respectively. Fifty-one percent did not have specific position and were multi tasking, 26 percent were clerk and the remaining were managers. The information revealed that most resorts in Lake Kenyir are small. Sixty-three percent of the respondents revealed that they were local people who lived in the surrounding area of Lake Kenyir and the remaining were from outside Lake Kenyir This information indicates that resorts in Lake Kenyir have recruited locals as their staff. All except one resorts, have been established for more than 10 years and have less than 10 fulltime employees. Only one resort has about 20 employees.

\subsection{Environmentally sensitive cultures}

The owners of the six resorts were asked dichotomous questions whether certain environmental sensitive practices were implemented in their resorts. Table 1 describes the questions and the results. All resorts claimed to incorporate ecological friendly material and all except one resort professed that their budget takes into account environmental saving and costs. Only 2 resorts incorporating waste recycling activities while the remaining sort to rubbish disposal. For the remaining items; low energy consumption devices, water saving practices, recycled material and local product, only 3 resorts claimed to practice them.

Table 1: Environmentally sensitive practices of Lake Kenyir resorts (owner's perspective).

\begin{tabular}{|c|c|c|c|}
\hline & Items & Yes & No \\
\hline A1 & $\begin{array}{c}\text { This resort quantifies its environmental saving and/or costs } \\
\text { in its budget }\end{array}$ & 5 & 1 \\
\hline A2 & $\begin{array}{c}\text { Provides facilities and services that incorporate low energy } \\
\text { and consumption devices }\end{array}$ & 3 & 3 \\
\hline A3 & $\begin{array}{c}\text { Provides facilities and services that incorporate water } \\
\text { saving practices }\end{array}$ & 3 & 3 \\
\hline A4 & $\begin{array}{c}\text { Provides facilities and services that incorporate recycling } \\
\text { of waste }\end{array}$ & 2 & 4 \\
\hline A5 & $\begin{array}{c}\text { Provides facilities and services that incorporate recycled } \\
\text { material }\end{array}$ & 3 & 3 \\
\hline A6 & $\begin{array}{c}\text { Provides facilities and services that incorporate ecological } \\
\text { friendly material }\end{array}$ & 6 & 0 \\
\hline A7 & $\begin{array}{c}\text { Provides facilities and services that incorporate local } \\
\text { product }\end{array}$ & 3 & 3 \\
\hline
\end{tabular}


Prior to the descriptive analysis, the researchers performed reliability test. The Cronbach's alpha value for 14 items was 0.715 indicating that it exceeds the recommended value of 0.6 by Peterson [38]. The reliability result indicates that the items used were reliable and consistent.

Table 2 represents the results of the descriptive analysis. Items B1, B2 and B3 represent environmental sensitive values where else the remaining items represent environmental sensitive practices or attitude. The data were interpreted following Alston and Miller [39], whereby mean scores between 1 and $1.49=$ strongly disagree, between 1.5 and $2.49=$ disagree, between 2.5 and $3.49=$ agree and between 3.5 and $4.00=$ strongly agree. Out of the total surveyed resorts, only 2 resorts incorporate waste recycling and only 50 percent practiced low energy and consumption devices, water saving practices, recycled material and

Table 2: $\quad$ Descriptive analysis.

\begin{tabular}{|c|c|c|c|c|}
\hline & Items & $\mathrm{N}$ & Mean & $\begin{array}{c}\text { Std. } \\
\text { Deviation }\end{array}$ \\
\hline B1 & $\begin{array}{c}\text { when humans interfere with nature it often produces } \\
\text { disastrous consequences }\end{array}$ & 51 & 3.22 & .702 \\
\hline B2 & mankind is severely abusing the environment & 49 & 2.43 & .979 \\
\hline B3 & I am happy to work in this ecotourism area & 51 & 3.12 & .765 \\
\hline B4 & $\begin{array}{l}\text { top management repeatedly communicates the } \\
\text { importance of ecological responsibility to the rest of } \\
\text { the company }\end{array}$ & 51 & 3.08 & .744 \\
\hline B5 & $\begin{array}{l}\text { top management stresses that protecting the } \\
\text { environment quality of life is one of the keys to the } \\
\text { firm's success }\end{array}$ & 51 & 3.16 & .731 \\
\hline B6 & our employees support environmental programs & 51 & 3.33 & .589 \\
\hline B7 & $\begin{array}{c}\text { our employees understand the importance of } \\
\text { environmental issues }\end{array}$ & 50 & 3.24 & .591 \\
\hline B8 & $\begin{array}{c}\text { the resort gives its employees training about } \\
\text { environmental issues }\end{array}$ & 50 & 2.80 & .808 \\
\hline B9 & the resort applies water-saving practices & 50 & 2.60 & .881 \\
\hline B10 & $\begin{array}{l}\text { the resort facilitates customer collaboration in } \\
\text { environment protection (e.g. voluntary changing of } \\
\text { towels) }\end{array}$ & 49 & 2.65 & .830 \\
\hline B11 & $\begin{array}{l}\text { the resort reduces the use of toxic and/or dangerous } \\
\text { products }\end{array}$ & 49 & 3.24 & .560 \\
\hline B12 & $\begin{array}{l}\text { in hiring employees, this resort gives priority to local } \\
\text { people (around lake kenyir) }\end{array}$ & 51 & 2.86 & .749 \\
\hline B13 & this resort emphasizes on traditional dress code & 51 & 2.31 & .812 \\
\hline B14 & $\begin{array}{l}\text { I often share information regarding the ethics in this } \\
\text { ecotourism area with visitors }\end{array}$ & 51 & 3.12 & .711 \\
\hline
\end{tabular}


local product. In terms of environmental sensitive values, the results show that employees in Lake Kenyir disagree that 'mankind is severely abusing the environment'. On the other hand, they believe that 'when humans interfere with nature it often produces disastrous consequences' and they are happy to work in an ecotourism area. In terms of environmental sensitive practices, employees of Lake Kenyir agree to all of the statements except for 'this resort emphasizes on traditional dress code' statement where the employees were disagree and received the lowest mean score. The highest mean score is 3.33 which show employees support for environmental programs, followed by an agreement that 'employees understand the importance of environmental issues' and 'the resort reduces the use of toxic and/or dangerous products'.

\section{Recommendation and conclusion}

This study found that a majority of resort owners in Lake Kenyir admitted to implementing an ecological friendly approach when conducting business. In terms of values, the present study concluded that the employees in Lake Kenyir have environmental sensitive values; they acknowledged the negative influence of human on nature and at the same time they enjoyed working in the ecotourism sector. In terms of practices, the study found that the resort operators implemented water-saving practices, emphasized on knowledge sharing on the need for environment protection to employees and customers. When it comes to employing staff, the resorts gave priority to locals. The resort operators did not emphasise on traditional dress code, probably because traditional dress was not suitable for rogue or outdoor activities.

Upon identifying the fact that resort operators adopt environmentally harmonious organizational cultures, the findings could provide some heading for policy implementations to enhance environmental protection awareness and activities in ecotourism areas. However, policy implementations should be carried out with care as they are greatly affected by the heterogeneity of small businesses.

Regulations and guidelines policies could be drawn up. Regulations are highly dependent with enforcement to ensure environment sustainability within ecotourism. The setting up of new regulations should be accompanied with proper enforcement to ensure functionality and full implementation of the set up regulations. Existing policies, i.e. which incorporate the implementation of GBI could be extended to tourism buildings. Policies to introduce green technology can be seen as another method to ensure environment harmony. More effort should be geared to encourage resort operators to incorporate green technologies.

In example, waste recycling and rain water harvesting are regarded to be low in cost and easy to be implemented. Market based instruments which are commonly used on a macro scale for stabilizing the economy, could also be used in this context of promoting environmentally harmonious culture. Policies which incorporate the use of market based instruments such as taxes and subsidies could give key players the proper push and incentives to ensure harmony with the environment. The existence of several resorts within an ecotourism 
destination presents an opportunity for the resorts to collaborate towards a collective action in environmental management. Partnerships, joint ventures and knowledge sharing could build the basis for an integrated method to solve environmental problems. From the sociological perspective, in order to preserve the identity and culture of the ecotourism destination, resort operators should also be encouraged to introduce local products in terms of food and cultural activities or games in their program.

There were some limitations faced in the course of the study. Firstly, the number of respondents in this study are only limited to a small number due to geographical constraints. A more thorough study which covers resort operators in all lake-based area in Malaysia is needed so that a more robust analysis can be done. Secondly, the size of the participating resorts was small, with less than 10 employees. Although this is a true scenario of resort operators population in Malaysian ecotourism destinations, the results cannot be generalised to large or medium size operators. Future research could be carried out to confirm whether the similar positive values and attitudes towards environment apply amongst other tourism service providers in Malaysia and in other countries.

\section{Acknowledgement}

The authors acknowledge the support of the Malaysian Government Research University (RU) Grant, which made this paper possible.

\section{References}

[1] Kaur, C. R., (2006), National Ecotourism Plan: Assessing Implementation of the Guidelines for Marine Parks, Unpublished Paper, Maritime Institute of Malaysia (MIMA).

[2] Malaysia Tourism Board (2010). Media Release. Retrieved from http://www.tourism.gov.my on 3 March 2010.

[3] Department of Statistics (2009). Economic Report 2008/2009, Department of Statistics \& Ministry of Finance, Malaysia, Retrieved on August 14 2009, from http://www2.treasury.gov.my

[4] Kedah Govt to Help Reopen Two Pedu Lake Resorts, (2007, February 13), BERNAMA, 1. Retrieved August 19, 2009, from ProQuest Central.

[5] Bjork, P. (2000). Ecotourism from a conceptual perspective, an extended definition of a unique tourism form. International Journal of Tourism Research, 2, 189-202.

[6] Altinay, M. and Hussain, K. (2005). Sustainable tourism development: a case study of North Cyprus. International Journal of Contemporary Hospitality Management, 17(3), pp. 272-280.

[7] Harrison, S., B. D. Inouye, and H. D. Safford. 2003. Ecological heterogeneity in the effects of grazing and fire on grassland diversity. Conservation Biology 17:837-845.

[8] Hillary R. (ed.). (2000). Small and Medium-Sized Enterprises and the Environment: Business Imperatives. Greenleaf: Sheffield. 
[9] Environment Agency. (2003). Environmental Impact Assessment in relation to water resources authorisations. Bristol: Environment Agency. http://www.environment-agency.gov.uk/static/documents/Research/eia.pdf access on 3 March 2010

[10] Storey, D.J. (1994). Understanding the Small Business Sector. Routledge: London.

[11] Thomas, R. (2000). Small Firms in the Tourism Industry: Some Conceptual Issues. International Journal of Tourism Research, 2, 345-353.

[12] Blangy, S. and M.E. Wood. 1993. Developing and implementing ecotourism guidelines for wildlands and neighboring communities. In $\mathrm{K}$. Lindberg and D. E. Hawkins (eds.). Ecotourism: A Guide for Planners and Managers. Bennington VT: The Ecotourism Society.

[13] Hofstede, G. (1980), Culture's Consequences, Sage, Beverly Hills, CA.

[14] Schein, E.H. (1997), Organisational Culture and Leadership, 2nd ed., Jossey-Bass, San Francisco, CA.

[15] Schein, E.H. (1984). Coming to a new awareness of organizational culture. Sloan Management Review, 25(2), pp.3-16.

[16] Kyriakidou, O. and Gore, J. (2005). Learning by example: Benchmarking organizational culture in hospitality, tourism and leisure SMEs. Benchmarking: An International Journal, 12(3), pp. 192-206.

[17] Chatman, J.A. and Jehn, K.A. (1994). Assessing the relationship between industry characteristics and organisational cultures: how different can you be? Academy of Management Journal, 37, 522-553.

[18] Ouchi, W.G. (1981). Theory Z: How American Business Can Meet the Japanese Challenge. Addison-Wesley, Reading, MA.

[19] Kilmann, R. Saxton, M.J. and Serpa, R. (1986). Issues in Understanding and Changing Culture. California Management Review, 28(2), pp. 87-94.

[20] Gardner, R.L. (1999). Benchmarking organizational culture: Organization culture as a primary factor in safety performance. Professional Safety, 44(3), pp. 26-32.

[21] Sathe, V. (1985). Culture and Related Corporate Realities: Text, Cases, and Readings on Organizational Entry, Establishment and Change. R.D. Irwin, Homewood, IL.

[22] Martin, E.G. and Terblanche, F. (2003). Building organisational culture that stimulates creativity and innovation. European Journal of Innovation Management, 6(1), 64-74.

[23] Dinan, C. and Sargeant, A. (2000). Social Marketing and Sustainable Tourism - is there a Match? International Journal of Tourism Research, 2, pp. 1-14.

[24] Wahab, S. and Pigram, J.J. (1997) (ed). Tourism, development and growth: the challenge of sustainability. London: Routledge.

[25] Lynn, N.A. and Brown, R.D. (2003). Effects of recreational use impacts on hiking experiences in natural areas. Landscape and Urban Planning 64(1-2), pp. 77-87. 
[26] Koens, J.F., Dieperink, C. and Miranda, M. (2009). Ecotourism as a development strategy: experiences from Costa Rica. Environment, Development and Sustainability. 11(6), 1225-1237.

[27] Dunlap, R.E., and Jones, R.E. (2002). Environmental Concern: Conceptual and Measurement Issues. In: R.E. Dunlap and W. Michelson (eds.). Handbook of Environmental Sociology Westport, CN: Greenwood Press. pp.482-524.

[28] Bamberg, S. (2003). How does environmental concern influence specific environmentally related behaviors? A new answer to an old question. Journal of Environmental Psychology, 23: 21-32.

[29] Stern, C. J., Lassoie, J. P., Lee, D. R., \& Deshler, J. D. (2003). How 'eco' is ecotourism? A comparative case study of ecotourism in Costa Rica. Journal of Sustainable Tourism, 11(4), 322-347.

[30] Alegre, J. and Garau, J. (2010). Tourist satisfaction and dissatisfaction. Annals of Tourism Research, doi:10.1016/j.annals.2009.07.001.

[31] Teh, L. and Cabanban, A.S. (2007). Planning for sustainable tourism in southern Pulau Banggi: An assessment of biophysical conditions and their implications for future tourism development. Journal of Environmental Management. 85(4), pp. 999-1008

[32] Blancas, F.J., Gonzalez, M., Lozano-Oyola, M. and Perez, F. (2010). The assessment of sustainable tourism: Application to Spanish coastal destinations. Ecological Indicators. 10, pp. 484-492.

[33] Lane B. (1992). Sustainable Tourism: A Philosophy. The Rural Tourism Unit, Department of Continuing Education, University of Bristol: Bristol.

[34] Jithendran, K.J. and Baum, T. (2000). Human Resources Development and Sustainability: The Case of Indian Tourism. International Journal of Tourism Research, 2, 40-421.

[35] Revell, A., Stokes, D. and Chen, H. (2009). Small Businesses and the Environment: Turning Over a New Leaf? Business Strategy and the Environment. DOI: 10.1002/bse.628. (www.interscience.wiley.com) access on 3 March 2010.

[36] Garland, R. (1991). The Mid-Point on a Rating Scale: Is it Desirable? Marketing Bulletin, 2, pp. 66-70.

[37] Trochim, W. M. (2006). Likert Scaling. Research Methods Knowledge Base, 2nd Edition. http://www.socialresearchmethods.net/kb/scallik.php. Retrieved 3 March, 2010.

[38] Peterson, R.A. (1994). A meta-analysis of Cronbach's coefficient alpha. Journal of Consumer Research, 21, pp. 381-391.

[39] Alston, A.J. and Miller, W.M. (2001). Analyzing the Barriers and Benefits toward Instructional Technology Instruction in North Carolina and Virginia Secondary Agricultural Education Curricula. Journal of Southern Agricultural Education Research, 51(1), 50-62. 